\title{
Stratigraphy and Fluoride Levels Variation in Borehole Water: A Case of River Njoro Catchment
}

\author{
George M. Ontumbi*, Thomas M. Munyao, Elias K. Ucakuwun \\ Department of Environmental Earth Sciences, University of Eldoret, Eldoret, Kenya \\ Email: *ontumbigeorge@yahoo.com
}

How to cite this paper: Ontumbi, G.M., Munyao, T.M. and Ucakuwun, E.K. (2020) Stratigraphy and Fluoride Levels Variation in Borehole Water: A Case of River Njoro Catchment. Open Access Library Journal, 7: e6388.

https://doi.org/10.4236/oalib.1106388

Received: May 1, 2020

Accepted: June 1, 2020

Published: June 4, 2020

Copyright $\odot 2020$ by author(s) and Open Access Library Inc.

This work is licensed under the Creative Commons Attribution International License (CC BY 4.0).

http://creativecommons.org/licenses/by/4.0/

\begin{abstract}
Boreholes are main sources of water for human use in the Rift Valley. However these boreholes have fluoride levels higher than the World Health Organization (WHO) recommended levels of $1.5 \mathrm{mg} / \mathrm{l}$ and consequently have raised serious health issues. This study sought to determine the relationship between borehole stratigraphy and fluoride levels in ground water in river Njoro catchment. This study adopted purposive longitudinal survey. The study adopted descriptive analysis of the borehole stratigraphy characteristics and fluoride levels recorded. The sources of data included; field surveys which were used to collect data on the borehole fluoride levels data and qualitative analysis of the stratigraphy data. From the results of the study, it was observed that the fluoride levels in boreholes in river Njoro catchment were dependent on the stratigraphy matrix of the boreholes. Therefore lithological formations have an influence on fluoride level River Njoro catchment. This study will form a pool of knowledge to other researchers who have an interest in the study of fluoride occurrence in ground water in the Rift Valley. Further the study will help in assisting the drillers in decision making after geological surveys of where to locate the boreholes.
\end{abstract}

\section{Subject Areas}

Environmental Sciences, Hydrology

\section{Keywords}

Stratigraphy, Boreholes, Fluoride Levels, Lithology and Field Survey

\section{Introduction}

Water, according to United Nations Environmental Programme (UNEP) is the 
basic requirement which determines the quality of life on earth. Good and quality water maintains healthy ecosystems thereby resulting in improved human welfare. Access to safe drinking water at national, regional and local levels is of important health and development related concerns as enshrined in Sustainable Development Goals (SDG) and UNEP [1]. Groundwater and specifically borehole water are considered unsuitable for human use when its chemical composition is not within the prescribed WHO standards for drinking water. The contaminants of great concern include: arsenic, fluoride, nitrate, iron, manganese, boron and most heavy metals whose presence should be within permissible limits. [2] observed that globally sufficient fresh water supplies are the foundations upon which all Sustainable Development Goals are based.

Groundwater quality would be linked and affected by the type of aquifer where the source of the borehole water is located as observed by [3]. Naturally the chemicals present in groundwater originate from the rocks and soil facilitated by the processes of percolation and infiltration. The hydrological processes of percolation and infiltration therefore have the potential of causing contamination, thereby affecting both the surface and ground water quality. Water for drinking should be free from pathogenic organisms and compounds that have adverse effects, immediate and long impacts on term on human health as observed by [4]. Generally contamination of groundwater associated with geogenic processes is dependent on the geological formations of specific areas. The contamination is justified when rainwater penetrates through the soil and gets in contact with the water table, thereby dissolving some minerals of the bedrock.

Consequently, the fluoride content of borehole water is a result of the dissolution of the bedrock along the borehole stratigraphic formations that are rich in varying fluorine bearing minerals. According to [5], the minerals forming the bedrock generally are a principal factor responsible for fluoride variations in fluoride levels in boreholes. According to [6] boreholes are the main sources of drinking water for a large percentage of the world's population. Groundwater is found in most environments; however without considering its quantity, quality, accessibility and recharge, it is determined by geology, geomorphology, land use and climatic variations. The significant role in storage, transportation and nature of borehole water is played by rock types and geomorphology. [7] observed that the geomorphological and geological attributes of a place where boreholes are located contribute to a recharge of $10-50 \mathrm{~mm}$ of fluoride levels in areas whose annual precipitation is less than $500 \mathrm{~mm}$.

[8] observed that in parts of India, Pakistan, West Africa, Thailand, China, Sri Lanka, and Southern Africa there are high groundwater fluoride concentrations associated rocks with volcanic and metamorphic rocks. Further [8] observe that in the 28 provinces of China, rampant cases of elevated fluoride levels have been reported in ground water sources. However comparatively shallow borehole sources had less concentrations as compared to deeper ground waters which recorded higher fluoride concentrations. [9] observed that fluoride levels of up to 
$10 \mathrm{mg} / \mathrm{l}$ in borehole water in the dry zone of Sri Lanka where cases of teeth and bone complications are serious. Severe and heavy rainfall resulting in prolonged dissolving of fluoride and other minerals in the wet Zone of Sri Lanka possibly associated with crystalline bedrock contribute to the much lower concentrations of fluoride as observed by [10].

The geological stratigraphic variation of Njoro catchment makes it a great potential to its borehole quality attributed to elemental composition as evidenced by the nearby phenomena of volcanicity thereby altering the water's fluoride levels. Therefore the levels of in the borehole water need to be quantified and thereafter the quality of water determined to ascertain if it exceeds the required WHO limits. Therefore there is need to solve the puzzle of the borehole stratigraphy dynamics and the fluoride levels variations in the River Njoro catchment.

\section{Materials and Method}

\section{Research Design}

This study adopted purposive longitudinal survey research design with water samples collected from 12 identified boreholes within the River catchment. The research design was purposive longitudinal survey because it sought to produce samples that were logically assumed to be representing the borehole stratigraphy in the Njoro catchment. The river catchment was arbitrary into three sections based on topography and elevation. Subsequently the sampled boreholes were located upstream, mid-stream and downstream of the river catchment. The sample boreholes had different depths with varying vertical borehole stratigraphic matrix. The water sampling from the boreholes was done during the rainy period and sunny seasons with intentions of capturing the seasonal variations during the study period. The research methodology adopted is represented in Figure 1.

\section{DESKTOP STUDIES}

Desktop study of the Njoro catchment, Literature review of Njoro catchment, acquisition of available secondary borehole data from the selected sample boreholes and studying of the sample borehole stratigraphy

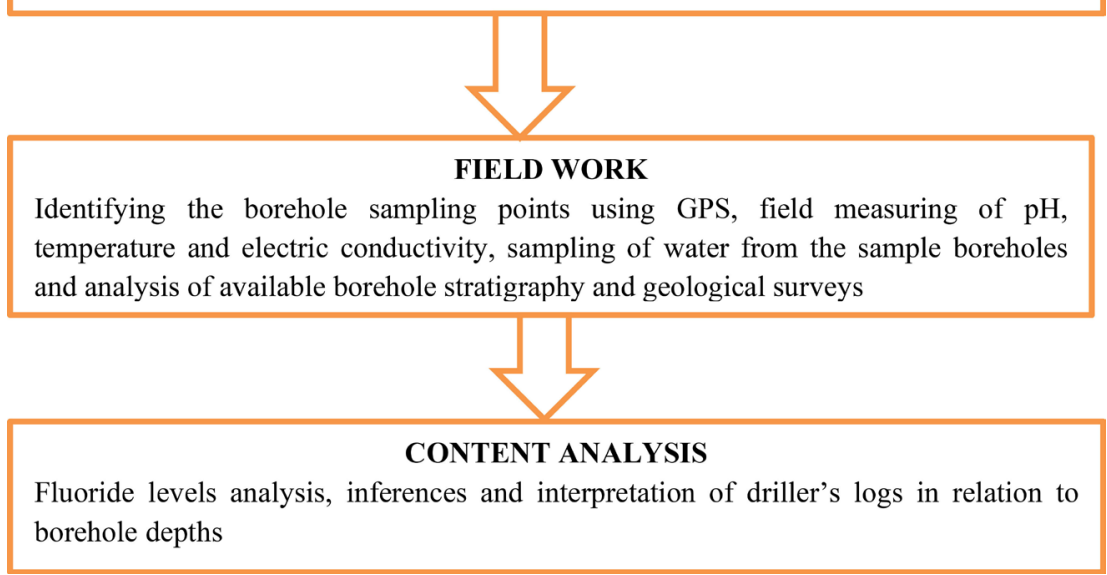

Figure 1. Field work procedure. 


\section{Data Collection and Sampling Procedure}

The borehole sampling sites are shown in Figure 2. Water was collected from the 12 boreholes within river Njoro Catchment during every fieldwork visit in 8 sampling trips. The sampled boreholes were longitudinally located upstream, midstream and downstream of the Njoro River Catchment. The respective GPS locations and depths of the boreholes are represented in Table 1. The boreholes were situated in both private and public lands were identified for sampling in the River Njoro Catchment. The identified boreholes within the Njoro River catchment were selected on the criteria of: depth, geographical location, and water use. A total of 84 water samples from the boreholes were collected from the identified 12 boreholes. The 84 samples comprised of 4 samples from each of the

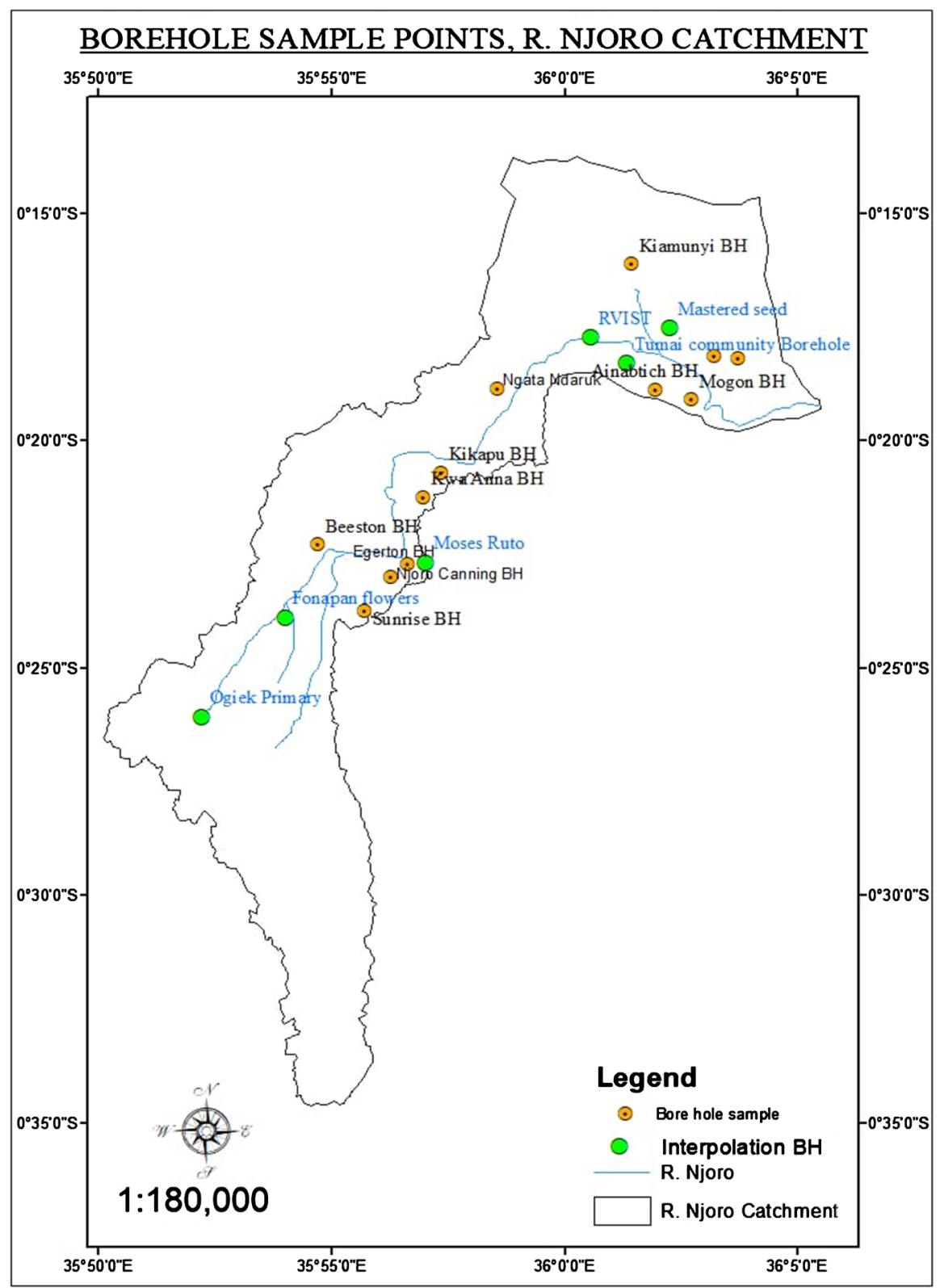

Figure 2. Borehole sampling points. 
Table 1. Borehole sampling points.

\begin{tabular}{ccccc}
\hline S/NO & GPS LOCATION & ALTITUDE & NAME & DEPTH \\
\hline 1 & $-0.362,35.907$ & 2450 & Beeston-Rurii & $130 \mathrm{M}$ \\
2 & $-0.3866,35.888$ & 2485 & Nesuit sec school & $180 \mathrm{M}$ \\
3 & $-0.397,35.945$ & 2307 & Egerton Sunrise & $172 \mathrm{M}$ \\
4 & $-0.362,35.987$ & 2142 & Kikapu community & $114 \mathrm{M}$ \\
5 & $-0.367,35.942$ & 2160 & Njoro canning & $230 \mathrm{M}$ \\
6 & $-0.367,35.992$ & 2156 & Kwa Annah & $207 \mathrm{M}$ \\
7 & $-0.305,35.988$ & 2043 & Ngata Ndaruk & $127 \mathrm{M}$ \\
8 & $-0.304,36.033$ & 1860 & Ainabtich community & $130 \mathrm{M}$ \\
9 & $-0.270,36.037$ & 1947 & Kiamunyi & $212 \mathrm{M}$ \\
10 & $-0.302,36.062$ & 1819 & Pistis & $180 \mathrm{M}$ \\
11 & $-0.304,36.050$ & 1794 & Mother Kelvin & $110 \mathrm{M}$ \\
12 & $-0.320,36.022$ & 1935 & Mogon Community & $140 \mathrm{M}$ \\
\hline
\end{tabular}

12 boreholes collected during the wet season between $10^{\text {th }}$ July and $18^{\text {th }}$ December 2019. Similarly 36 samples were collected from the 12 boreholes in 3 fieldwork visits during the dry seasons between $10^{\text {th }}$ January and $10^{\text {th }}$ May 2019 . Similarly the researcher collected data on the borehole stratigraphy and geological surveys from the borehole owners. The data on the boreholes stratigraphy was available as per the varied dates when the boreholes' drilling was completed. The stratigraphy data and borehole surveys from the borehole owners were also supplemented by data that was collected from the Water Resource Authority (WRA) Nakuru office.

\section{Borehole Water Sampling Protocol}

The borehole water was pumped and made to pass through a flow through cell and allowed some time for the stabilization of temperature, $\mathrm{pH}$ and Electrical conductivity parameters. Upon the stabilization of these physical parameters of water quality, the water samples were collected into clean washed $50 \mathrm{ml}$ plastic sampling bottles. The sampling bottle and its lid were rinsed three times using the pumped borehole water, and thereafter the samples collected were filtered using Whatman Glass Fibre Filters $(0.45 \mu \mathrm{m}, \mathrm{GF} / \mathrm{C})$ as shown in Plate 1 and Plate 2. The sample ID indicating the physical location and date of the sampling was written on a label stuck on the bottle, with a waterproof pen. Thereafter the bottle was tightly closed and the water samples were refrigerated and transported in a cool box to the Chemistry Laboratory at the University of Eldoret for fluoride analysis.

\section{Climatic Characteristics of the Study Area}

Rainfall patterns within the River Njoro Catchment are extremely variable both spatially and temporal and in terms of rainfall intensities. This makes the natural flows of water in the river Njoro and its tributaries highly variable in space and time. The climate is characterized by a trimodal precipitation pattern: 


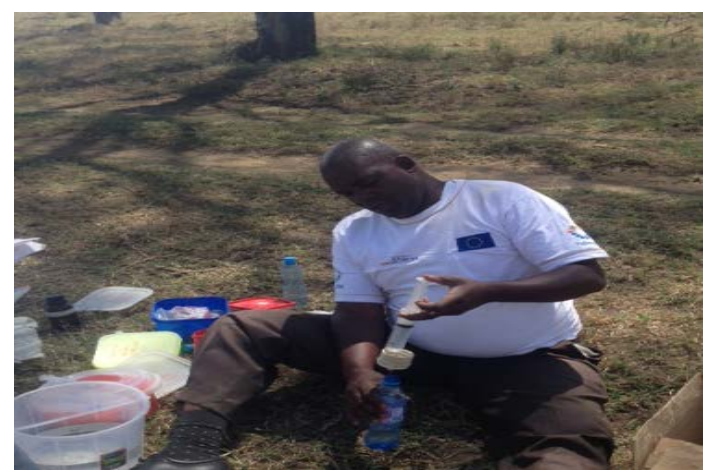

Plate 1. Filtering the water samples during field sampling.

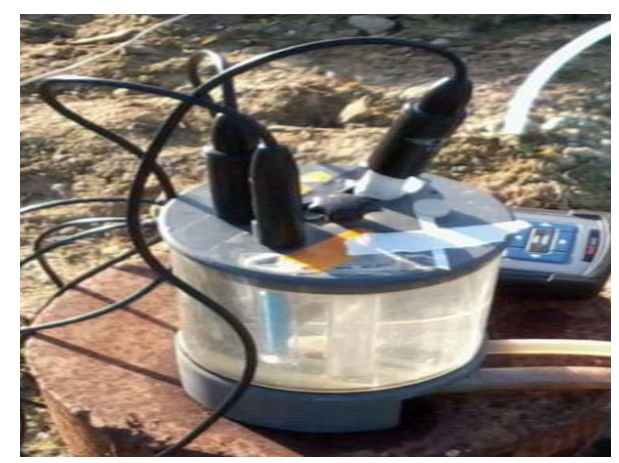

Plate 2. Measuring physical parameters in situ.

High and heavy rains from April to May; little, intense rains in August; and shorter, less intense rains from November to December. Total annual precipitation is $956 \mathrm{~mm}$, and the mean annual temperature is $16.5^{\circ} \mathrm{C}$, ranging from a minimum of $9^{\circ} \mathrm{C}$ (July) to a maximum of $24^{\circ} \mathrm{C}$ January.

\section{Data Analysis}

\section{Water Samples}

The water samples were collected in clean $50 \mathrm{ml}$ plastic bottles, transported in a cooling box to the University of Eldoret Chemistry Laboratory, and then stored at negative $20^{\circ} \mathrm{C}$ before analysis for fluoride. Fluoride was determined using an Orion ${ }^{\circledR}$ model 94-09 and model 96-09 combination fluoride electrodes. Millivolt readings were taken on $3.0 \mathrm{~mL}$ portions of samples adjusted to $\mathrm{pH} 5.0$ - 5.5 after mixing with $0.3 \mathrm{~mL}$ of TISAB III (total ionic strength adjustment buffer, Orion ${ }^{\circledR}$ 94-09-11). For calibration, $0.30 \mathrm{~mL}$ of TISAB III was mixed with $3.0 \mathrm{~mL}$ portions of standard solutions containing 0.02, 0.10, 1.00, and $10.0 \mathrm{ppm}$ F-prepared by diluting a 100 ppm F-stock solution (Orion ${ }^{\circledR}$ 94-09-0) with deionized water. A nearly linear calibration curve was drawn by plotting the average millivolt reading for each standard against the fluoride concentration on semi-logarithmic paper. To determine the variation in fluoride levels, means of measured quantities were calculated for all the sampled boreholes and the data presented in a table. The variation in fluoride levels was explained in reference to variation in borehole stratigraphy of individual boreholes. 


\section{Borehole Stratigraphy}

Borehole stratigraphy data for the sampled 12 boreholes was analysed to determine lithology and geological characteristics of the aquifers. Aquifer material was determined by examining entire rock matrix and strata of the borehole as was shown in the driller's logs with lower strata considered as the main aquifers. Schematic formations for the individual sampled boreholes at upstream, midstream and downstream were drawn to represent the boreholes' stratigraphy. The fluoride levels in the sampled boreholes were also qualitatively correlated to the stratigraphy formations of each borehole by pointing the main strata as the two strata at the base of the boreholes.

\section{Results}

\section{Schematic Presentation of Borehole Stratigraphy}

Geological formations of the boreholes in river Njoro catchment were obtained from the driller's logs and in some cases compared with available geological surveys that were done before the boreholes were drilled. The schematic stratigraphy shows the sequence of the possible aquifers of the boreholes. The lithological analyses identified four types of aquifer matrices; sediments (including volcanic ashes), trachyte, phonolites and tuffs.

\section{Stratigraphic Formations for Downstream Boreholes}

The downstream boreholes are located in the lower end of the River Njoro catchment. The four downstream boreholes; Pistis, Mother Kelvin, Ainabtich and Mogon as presented in Figure 3 varied in depth and stratification. The stratigraphy analysis indicated that the aquifer distributions varied from sixteen to eighteen aquifer systems with eight major aquifer strata. The major lithologies included; Phonolites, Tuffs, Trachytes, Pumice, Volcanic Ash and Volcanic rock. Lithological logs analyses showed aquifer thickness variation that ranged from 2 to 46 meters. The aquifer matrix of Mogon and Pistis boreholes were made up of Tuff, Lava, Phonolites and Pumice rocks matrix. On the contrary the Mother Kelvin and Ainabtich boreholes had the Clay, Tuff and Phonolite rock matrix. Moreover Mogon and Pistis boreholes recorded higher levels of fluoride of 8.798 $\mathrm{mg} / \mathrm{l}$ and $19.369 \mathrm{mg} / \mathrm{l}$ respectively as compared to the Mother Kelvin and Ainabtich which recorded low levels of fluoride of $3.72 \mathrm{mg} / \mathrm{l}$ and $5.53 \mathrm{mg} / \mathrm{l} \mathrm{respec-}$ tively. The stratigraphy and aquifer associated with Tuff strata as demonstrated by Mogon and Pististis boreholes is associated with high fluoride levels.

The four midstream boreholes; Kwa Annah, Umoja Kikapu, Ngata Mbaruk and Kiamunyi had different depths. The borehole stratigraphy and corresponding depths of the midstream boreholes are presented in Figure 4. The stratigraphy analysis of the midstream boreholes indicated that aquifer distribution varied from four to nine aquifer strata with nine major aquifer strata. The major lithologies included; Clay, Tuffs, Volcanic Soil, Sandy Soil, Black Top Soil, Pumice, Phonolites and Trachytes occurring at varied intervals and depths. The analyses showed aquifer thickness variation that ranged from 2 to 46 meters. The 
Stratigraphic Formations for downstream Boreholes

\begin{tabular}{|c|}
\hline Sandy soils \\
\hline Tuff \\
\hline Phonolites \\
\hline Tuff \\
\hline
\end{tabular}

Pistitis

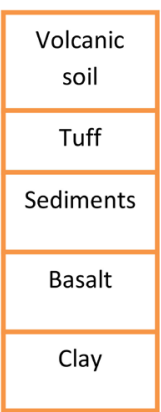

Mother Kelvin

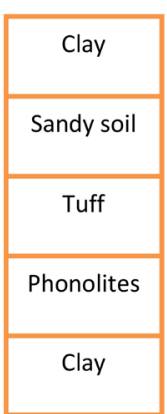

Ainabtich

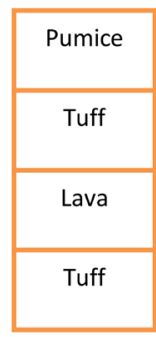

Mogon

Figure 3. Lithological formations of downstream boreholes.

Stratigraphic Formations for Midstream Boreholes

\begin{tabular}{|c|}
\hline $\begin{array}{c}\text { Black top } \\
\text { soil }\end{array}$ \\
\hline Clay \\
\hline Trachyte \\
\hline Phonolites \\
\hline
\end{tabular}

KWA ANNAH

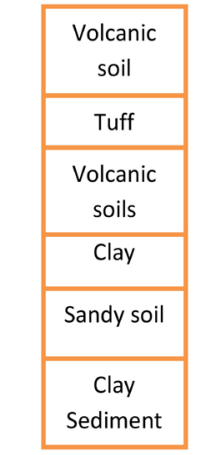

UMOJA KIKAPU
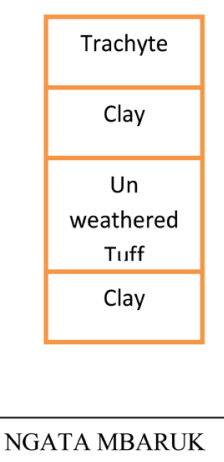

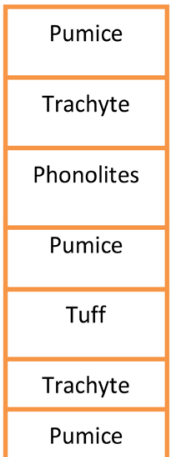

Pumice

KIAMUNYI

Figure 4. Lithological formations of midstream boreholes.

average levels of fluoride in the borehole water ranged from $18.59 \mathrm{mg} / \mathrm{l}$ at the Kiamunyi borehole being the highest to $1.74 \mathrm{mg} / \mathrm{l}$ at the Ngata Mbaruk borehole being the lowest. The Umoja Kikapu and Kwa Annah boreholes recorded 2.91 and $3.32 \mathrm{mg} / \mathrm{l}$ of fluoride levels respectively. Kiamunyi borehole has many layers composed of Pumice, Tuff and Trachyte.

\section{Stratigraphic Formations for Upstream Boreholes}

The four upstream boreholes; Egerton sunrise, Njoro canning, Biston Ruri community and Nesuit primary school borehole varied in depth. Stratigraphy analysis indicated that aquifer distribution varied from nine to eighteen aquifer systems with seven major aquifer strata as presented in Figure 5. The major lithologies included; Clay, Tuffs, Basalts, Volcanic, Pumice, Phonolites and Trachytes occurring at varied intervals and depths. The analyses showed that aquifer had variation in aquifer strata. Pyroclastics formed the top most part of the stratigraphy. The aquifer of Njoro Sunrise and Njoro canning boreholes was made up of Tuff, Lava and Pumice rocks matrix. On the contrary the Beeston Ruri and Nesuit school boreholes had the Clay, Tuff, Sediments and Phonolite rocks matrix. Moreover Njoro sunrise and Njoro canning boreholes recorded higher levels of fluoride of $4.00 \mathrm{mg} / \mathrm{l}$ and $5.89 \mathrm{mg} / \mathrm{l}$ respectively as compared to 
the Beston Ruri and Nesuit School which recorded low levels of fluoride of 3.41 $\mathrm{mg} / \mathrm{l}$ and $3.00 \mathrm{mg} / \mathrm{l}$ respectively.

\section{Average Fluoride Levels of the Sampled Boreholes}

The average levels of fluoride in the respective sampled boreholes and the main aquifers are presented in Table 2. The average fluoride levels represent the average fluoride levels recorded in the samples collected from the borehole during the eight field trips.

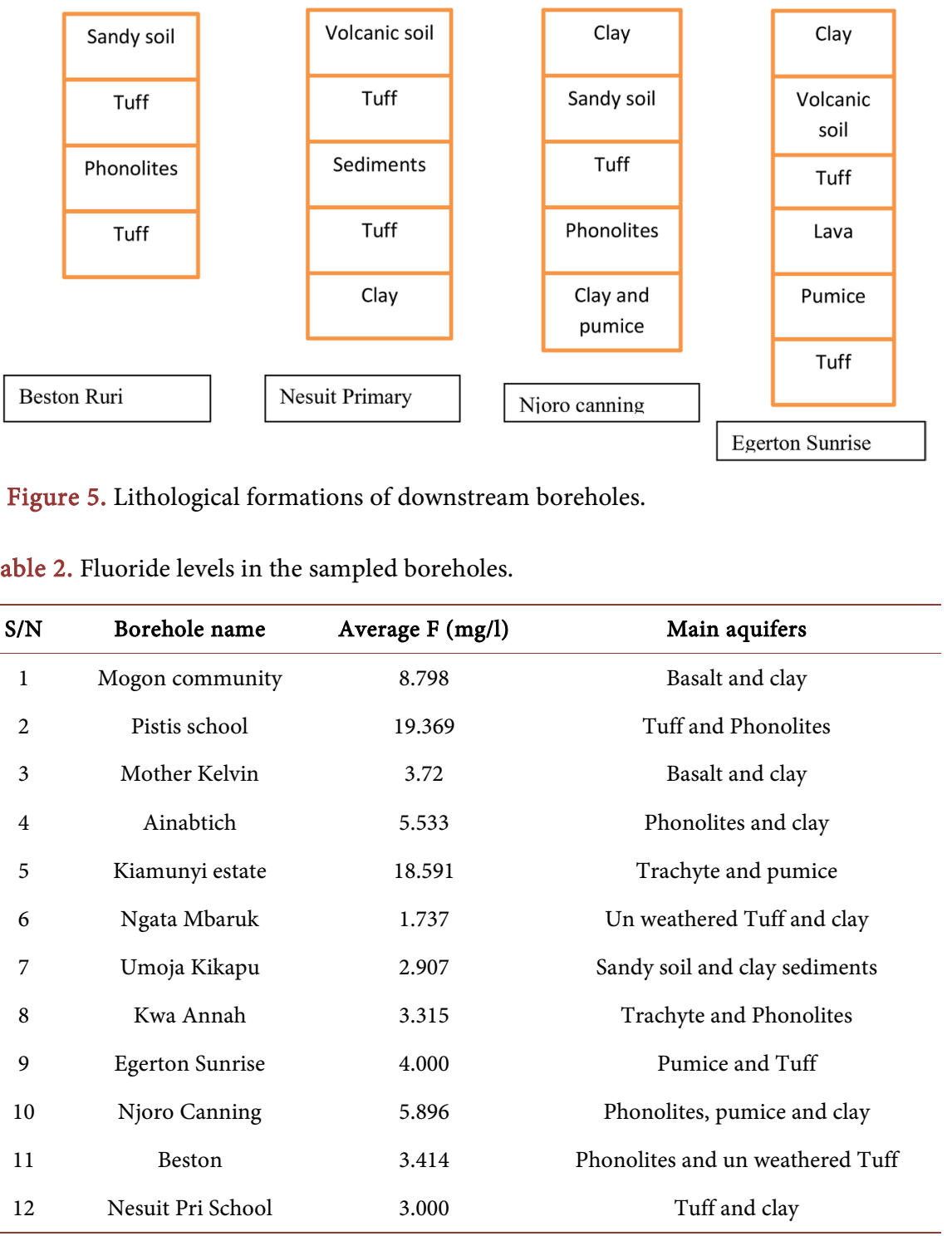

\section{Discussion}

In this study the sampled boreholes were of different depths comprising of different lithologies and water aquifers. Similarly despite their relative physical locations the boreholes recorded varying levels of fluoride from their water samples. Therefore the borehole lithologies or matrix depend on the fluoride levels in boreholes. The same observations were made by [11] who asserted that high 
fluoride concentrations are influenced more by lithology matrix of a borehole and composition of the aquifer. Further also [12] observes that levels of fluoride in the aquifers of boreholes depend on the mineralogy and lithology. Therefore interaction between groundwater and different geological units of variable mineralogy results in different fluoride levels in boreholes as a result of reactions in the boreholes. The reactions include; dissolution-precipitation, ion exchange, oxidation-reduction and absorption which can change water chemistry. Majority of the boreholes in the Njoro River Catchment have higher fluoride levels than river water as justified by Kiamunyi having $18.591 \mathrm{mg} / \mathrm{l}$, Pistis School 19.369 $\mathrm{mg} / \mathrm{l}$ and Mogon Community having $8.798 \mathrm{mg} / \mathrm{l}$.

The levels of fluoride in the Rift System groundwater vary significantly from place to place depending on the influence exerted by local geology within the Rift Valley. Moreover it is generally accepted that prolonged contact of the water with the rock fluoride build-up in groundwater results to high fluoride levels. Lithology therefore becomes an important determinant of groundwater fluoride concentration. [13] observes that bedrock aquifers in alkaline magmatic rocks and metamorphic rocks are particularly associated with fluoride contaminated groundwater with fluorspar, fluorapatite, amphiboles and certain micas being the minerals directly responsible for its release.

The geogenic contamination results in occurrence of high fluoride in groundwater. The sampled boreholes in river Njoro in this study equally displayed varied geological formations and varied fluoride levels. Geogenic contamination of conversely depends on the stratigraphic formations of an area. As rainwater infiltrates through the soil and reaches the water table, it dissolves components of bedrock. Consequently therefore fluoride in groundwater originates from dissolution of fluorine bearing minerals in the bedrock [5]. The fluoride high levels in ground water in Njoro catchment would be attributed to percolation of groundwater through the weathered rock in the aquifers, where it dissolves fluoride-bearing minerals thereby releasing fluoride in solution form into the boreholes. Similarly [14] observes that long residence with fluoride bearing rocks results to high fluoride levels in the boreholes.

In all the sampled borehole in this study there was a significant variation in the levels of fluoride recorded with the Kiamunyi recording the highest while the borehole at Umoja Kikapu recorded the lowest levels. Similarly, [8] alludes that due to the large number of variables, fluoride concentrations in groundwater can vary from well under $1 \mathrm{mg} / \mathrm{L}$ to more than $35 \mathrm{mg} / \mathrm{L}$. In Tanzania studies have shown that the problem of high fluoride content in groundwater is very acute in mainland Tanzania [15]. In Tanzania the high fluoride level is contributed by geological processes such as volcanic activities, thermal springs and the presence of minerals such as fluorite and apatite in rocks. [15] found that borehole water in South Sanya corridor contained up to $96 \mathrm{mg} / \mathrm{l}$ fluoride whereas the area west of Ngorongoro Crater had fluoride content of between 40 and $140 \mathrm{mg} / \mathrm{L}$ in spring water. 
Trachytes, Tuff and Pumice strata matrix at Kiamunyi and Mogon boreholes recorded high fluoride levels in River Njoro catchment. Similar findings were presented by [16] who observed that Trachytes are fine-grained lava with an alkaline composition, typically with prominent large alkali feldspar crystals. Further [16] observe that Trachytes together with tuffs were deposited at the edges of rift escarpments associated with elevated fluoride levels. Unconsolidated fragmentary deposits are eroded from volcano, reworked and deposited on land. Subsequently the compositions of these volcano sediments are related to the parent rock and therefore after weathering contribute to higher fluoride levels.

\section{Conclusion}

The study concludes that high fluoride levels in the boreholes located in the Njoro River Catchment; Pistis 19.369 mg/l, Kiamunyi $18.591 \mathrm{mg} / \mathrm{l}$ and Mogon $80,798 \mathrm{mg} / \mathrm{l}$ are results of contact of the water with fluoride rich rocks which form aquifers of the boreholes. The contribution of volcanic rocks on fluoride levels in boreholes was justified by the drillers' logs which identified four major dominant aquifer matrix as: sediments, trachyte, tuffs and pyroclastics. Geological formations of the boreholes within the Njoro river catchment are of multi lithological formations of volcanic rocks in nature. The rocks included: trachytes, basalts, phonolites, tuffs and volcanic sediments. This study will form a background of knowledge to other researchers who have an interest in the study of fluoride occurrence in ground water in the Rift Valley. Finally further the study will assist the drillers in decision making after geological surveys of where to locate the boreholes.

\section{Conflicts of Interest}

The authors declare no conflicts of interest regarding the publication of this paper.

\section{References}

[1] Alcamo, J. (2019) Water Quality and Its Interlinkages with the Sustainable Development Goals. Current Opinion in Environmental Sustainability, 36, 126-140. https://doi.org/10.1016/j.cosust.2018.11.005

[2] Parris, T.M. and Kates, R.W. (2003) Characterizing a Sustainability Transition: Goals, Targets, Trends, and Driving Forces. Proceedings of the National Academy of Sciences, 100, 8068-8073. https://doi.org/10.1073/pnas.1231336100

[3] Alberta Environment (2009) Focus on Groundwater Quality and Quantity. Alberta Environmental-Information Centre, Oxbridge.

[4] Bartram, J., Cotruvo, J.A., Exner, M., Fricker, C. and Glasmacher, A. (2003) Heterotrophic Plate Counts and Drinking-Water Safety. IWA Publishing, London. https://doi.org/10.1016/j.ijfoodmicro.2003.08.005

[5] Chae, G.Y., Seong, T.M., Bernhard, K., Kyoung-Ho, K. and Seong-Yong, K. (2007) Fluorine Geochemistry in Bedrock Groundwater of South Korea. Science of the Total Environment, 385, 272-283. https://doi.org/10.1016/j.scitotenv.2007.06.038 
[6] Brindha, K. and Elango, L. (2011) Fluoride in Groundwater: Causes, Implications and Mitigation Measures. In: Monroy, S.D., Ed., Fluoride Properties, Applications and Environmental Management, Nova Publishers, New York, 111-136.

[7] MacDonald, A.M., Bonsor, H.C., Dochartaigh, B.E. and Taylor, R.G. (2012) Quantitative Maps of Groundwater Resources in Africa. Environmental Research Letters, 7, Article ID: 024009. https://doi.org/10.1088/1748-9326/7/2/024009

[8] Edmunds, W.M. and Smedley, P.L. (2013) Fluoride in Natural Waters. In: Essentials of Medical Geology, Springer, Berlin, 311-336. https://doi.org/10.1007/978-94-007-4375-5_13

[9] Hallett, B.M., Dharmagunawardhane, H.A., Atal, S., Valsami-Jones, E., Ahmed, S. and Burgess, W.G. (2015) Mineralogical Sources of Groundwater Fluoride in Archaen Bedrock/Regolith Aquifers: Mass Balances from Southern India and North-Central Sri Lanka. Journal of Hydrology: Regional Studies, 4, 111-130. https://doi.org/10.1016/j.ejrh.2014.10.003

[10] Dissanayake, C.B. (1991) The Fluoride Problem in the Groundwater of Sri Lanka Environmental Management and Health. International Journal of Environmental Health Studies, 38, 137-156. https://doi.org/10.1080/00207239108710658

[11] Nyamboge, C., Karoli, N.N., George, V.L. and Alfred, N.N.M. (2018) Hydrogeochemical Characteristics and Spatial Distribution of Groundwater Quality in Arusha Well Fields, Northern Tanzania. Applied Water Science, 8, Article No. 118.

[12] Ghiglieri, G., Balia, R., Oggiano, G. and Pittalis, D. (2010) Prospecting for Safe (Low Fluoride) Groundwater in the Eastern African Rift: The Arumeru District (Northern Tanzania). Hydrology and Earth System Sciences, 14, 1081-1091. https://doi.org/10.5194/hess-14-1081-2010

[13] Sankar, K., Dar, M.A. and Dar, I.A. (2011) Fluorine Contamination in Groundwater: A Major Challenge. Environmental Monitoring and Assessment, 173, 955-968. https://doi.org/10.1007/s10661-010-1437-0

[14] Saxena, V.K. and Ahmed, S. (2003) Inferring the Chemical Parameters for the Dissolution of Fluoride in Groundwater. Environmental Geology, 43, 731-736. https://doi.org/10.1007/s00254-002-0672-2

[15] Mjengera, H. and Mkongo, G. (2002) Appropriate Technology for Use Influoritic Areas in Tanzania. Physics and Chemistry of the Earth, 28, 1097-1104.

[16] Kanda, I. and Suwai, J. (2013) Hydrogeochemistry of Shallow and Deep Water Aquifers of Menengai Geothermal Area, Kenya Rift Valley. GRC Transactions, 37, 403-410. 